\title{
Second Eastern Mediterranean/Arab States regional summit of national ethics and bioethics committees
}

Citation: Second Eastern Mediterranean/Arab States regional summit of national ethics and bioethics committees. East Mediterr Health J. 2020;26(5):620-621 https://doi.org/10.26719/2020.26.5.620

Copyright $($ C World Health Organization (WHO) 2020. Open Access. Some rights reserved. This work is available under the CC BY-NC-SA 3.0 IGO license (https://creativecommons.org/licenses/by-nc-sa/3.o/igo).

\section{Introduction}

At the 11th Global Summit of National Ethics/Bioethics Committees, held in Berlin, Germany, 16-18 March 2016 (1), it was proposed to hold regional summits between global summits to discuss bioethical issues relevant to particular regions. The first Eastern Mediterranean/Arab States regional summit was held by the United Nations Educational, Scientific and Cultural Organization (UNESCO) and the World Health Organization (WHO) in Muscat, Oman, 5-6 April 2017, in collaboration with the Omani National Bioethics Committee and Sultan Qaboos University (2). Two years later, the second summit, jointly organized by the UNESCO Regional Bureau for Sciences in the Arab States and WHO Regional Office for the Eastern Mediterranean, was held at the WHO Regional Office in Cairo, Egypt, on 15-16 December 2019 (3). The summit was followed by a workshop on training of trainers for ethics in implementation research, held at the WHO Regional Office, Cairo, 17 December 2019 (4).

Participants of the regional summit included representatives of national ethics and bioethics committees, ministries of health and higher education, academic and research institutions, and the League of Arab States, as well as international experts and staff from WHO and UNESCO. The overall aims of the second regional summit were to explore a regional approach to ethics policy processes and share experiences in promoting ethics, prior to the 13th global summit (which was planned to be held in Portugal during 2020).

The specific objectives of the summit were to:

- follow up on outcomes of the first regional bioethics summit;

- discuss outcomes of the last global bioethics summit held in 2018 and plan for the upcoming summit in 2020;

- outline and discuss methods of regional collaboration, with a special focus on fostering national ethics/ bioethics committees;

- develop strategies to strengthen linkages between bioethics committees and policy-makers (ministries of health, education, science and technology); and
- share experiences and deliberate on current ethical issues, such as migration ethics and artificial intelligence.

\section{Summary of discussions}

During the meeting, linkages were established between bioethics committees and policy-makers, who were provided with evidence-based advice. The high quality of exchange between organizations was fruitful, as illustrated by WHO/UNESCO collaborative activities on one hand, as well as League of Arab States/UNESCO cooperation on the "Charter of Ethics of Science and Technology in the Arab Region" (5), on the other. It was stressed that at the political level, proposals are usually welcomed, adopted and supported during the meetings of ministers of health, showing real political will (for the Charter). In addition, it was also noted that WHO can help to assist national ethics/bioethics committee teams in their accreditation processes.

\section{Recommendations}

To WHO

- Enhancing multisectoral involvement in the work of national ethics/bioethics committees, including the media and civil society.

- Fostering bioethics principles within health sciences' curricula and beyond.

- Building the capacities of health care providers in medical and research ethics.

To Member States

- Promoting the use of new tools, such as virtual training, rather than face-to-face training.

- Strengthening training-of-trainers (TOT) courses in bioethics.

- Extending networking to national ethics/bioethics committees beyond the Region.

- Developing a roadmap on improving national capacity in bioethics and an action plan for implementation.

- Developing bylaws and regulations addressing the main ethical issues.

1 This report is based on the Summary Report on the Second Eastern Mediterranean/Arab States regional summit of national ethics and bioethics committees, 15-16 December 2019, Cairo, Egypt (http://applications.emro.who.int/docs/EMRPCo47E.pdf?ua=1). 


\section{References}

1. World Health Organization. Past Global Summits of National Bioethics Committees. Geneva: World Health Organization; 2020 (https://www.who.int/ethics/globalsummit/summits/en/)

2. World Health Organization Regional Office for the Eastern Mediterranean (WHO/EMRO). Eastern Mediterranean/Arab states regional summit of national ethics and bioethics committees. Cairo: WHO/EMRO; 2017 (http://www.emro.who.int/fr/rpc/rpcevents/regional-summit-of-national-ethics-and-bioethics-committees.html).

3. World Health Organization Regional Office for the Eastern Mediterranean (WHO/EMRO). National Ethics/Bioethics Committees, Cairo: WHO/EMRO; 2019 (http:/www.emro.who.int/rpc/rpc-news/eastern-mediterraneanarab-states-regional-summit-of-national-ethics-and-bioethics-committees-cairo-egypt-1516-december-2019.html?format=html).

4. World Health Organization Regional Office for the Eastern Mediterranean (WHO/EMRO). First training of trainers on ethics in implementation research. Cairo: WHO/EMRO; 2019 (http://www.emro.who.int/rpc/rpc-news/first-training-of-trainers-on-ethics-in-implementation-research.html).

5. UNESCO Office Cairo and Regional Bureau for Science in the Arab States. Charter of Ethics of Science and Technology in the Arab Region. Cairo: UNESCO; 2019 (https://unesdoc.unesco.org/ark:/48223/pfooo0372169). 